4. Бех І. Д. Особистість на шляху до духовних цінностей : монографія / І. Д. Бех. - Київ - Чернівці : Букрек, 2018. - 296 с.

5. Срмак Г. В. Аналіз морального виховання у працях радянських $\mathrm{i}$ сучасних дослідників : історичний аспект / Г. В. Срмак // Науковий вісник Мелітопольського державного педагогічного університету. Серія : Педагогіка. - 2014. № 1. - C.261-265. URL : http://nbuv.gov.ua/UJRN/ Nvmdpu 2014147

6. Каган $\overline{\mathrm{M}} . \overline{\mathrm{C}}$. Философская теория ценности / М. С. Каган. - Санкт-Петербург : ТОО ТК «Петрополис», 1997. - 205 c. - URL : https://www.logicbooks. info/sites/default/files/kagan. filosofskaya teoriya cennosti.pdf (дата звернення: 10.09.2019).

7. Ковтун Н. М. Співвідношення морального і вольового у контексті дослідження соціальної активності / Н. М. Ковтун // Гуманітарний вісник Запорізької державної інженерної академії : зб. наук. пр. / гол. ред. В. Г. Воронкова. - Запоріжжя : Вид-во ЗДІА, 2013. - Вип. № 53.

8. Нова українська школа. Концептуальні засади реформування середньої школи. URL : https:// www.kmu.gov.ua/storage/app/media/reforms/ukrainskashkola-compressed.pdf (дата звернення: 09.09.2019).

9. Сухомлинский В. А. Потребность человека в человеке / В. А. Сухомлинский. - 2-е изд. - М., 1981. $93 \mathrm{c}$.

10. Федорова М. А. Моральні цінності особистості : сутність поняття та основні характеристики / М. А. Федорова // Проблеми освіти: збірник наукових праць. - Спецвипуск. - Вінниця - Київ, 2015. C. 105-109.

Дата надходження до редакиії: 13.09.2019 p.

\title{
БІБЛІОГРАФІЧНА СКЛАДОВА СИСТЕМИ ІНФОРМАЦІЙНОГО СУПРОВОДУ НАУКОВИХ ДОСЛІДЖЕНЬ ІЗ НАЦІОНАЛЬНО-ПАТРІОТИЧНОГО ВИХОВАННЯ
}

У статті проаналізовано зміст $i$ структуру науково-допоміжного бібліографічного покажчика «Національно-патріотичне виховання в Україні» (2014-2018 рр.). Узагальнено основні наукові підходи до класифікації бібліографічних видань, наявних y бібліографічному науковому дискурсі та бібліографічній практииі. Зосереджено увагу на основних складових національно-патріотичного виховання: громадсько-патріотичному, військово-патріотичному та духовно-моральному вихованні. Констатовано, що формальні та змістові характеристики бібліографічних видань перебувають у постійній динамічній рівновазі, шзо обумовлено соиіальними, а також інформачійними чинниками розвитку суспільних відносин.

Ключові слова: науково-допоміжний бібліографічний покажчик, національно-патріотичне виховання, наукові дослідження, заклади освіти, військово-патріотичне виховання, військово-патріотичне виховання, духовно-моральне виховання.

В статье представлен анализ содержсания и структуры научно-вспомогательного библиографического указателя «Национально-патриотическое воспитание в Украине» (2014-2018 га.). Обобщчены основные научные подходы к классификации библиографических изданий, имеющихся в библиографическом научном дискурсе и библиографической практике. Сосредоточено внимание на основных составляющих национально-патриотического воспитания: общественно-патриотическом, военно-патриотическом и духовно-нравственном воспитании. Констатировано, что формальнье и содержстельные характеристики библиографических изданий находятся в постоянном динамическом равновесии, что обусловлено сочиальными, а также информационными факторами развития общественньх отношений.

Ключевые слова: научно-вспомогательный библиографический указатель, национально-патриотическое воспитание, научные исследования, учебные заведения, военно-патриотическое воспитание, военно-патриотическое воспитание, духовно-нравственное воспитание.

The Content and Structure of the scientific-auxiliary bibliographic Index «National patriotic Education in Ukraine» (2014-2018) are analyzed. The Relevance of the Chosen topic is Substantiated and the 
main normative-legislative Documents that influenced the Formation of the systematic, organized According to the bibliographic Criteria of the Edition "NationalPatriotic Education in Ukraine» are highlighted. The basic scientific Approaches to the Classification of bibliographic Publications existing in bibliographic scientific Discourse and bibliographic Practice are generalized. The Focus is on the Components of nationalpatriotic Education: public-patriotic, military-patriotic and spiritual-moral Education. The Uniqueness of the selected Materials published on the global EBSCO Platform, which are reflected in the Contents of the Index, is confirmed, and it is hoped that in the Future such a Trend can become a demanded and perspective Direction of bibliographic Research and will influence the Expansion of the Audience at the expense of foreign Users. bibliographical Manuals on such topics. It has been stated that Publications in electronic Form, in particular, are published on the Content of open journal Systems, which also formats and reveals new Trends in bibliographic Matters. It is stated that the prepared scientific-auxiliary bibliographic Index will promote and improve the Forms and Methods of Realization of tasks of national-patriotic Education in Ukraine, will promote the Introduction into Practice of educational Establishments of different Levels of creative Development of Specialists in the Field of patriotic Education. It is stated that the formal and substantive Characteristics of bibliographic Publications are in constant dynamic Equilibrium, which is caused by social, informational Factors of the Development of social Relations.

Key words: scientific-auxiliary bibliographic Index, national-patriotic Education, information Support, scientific Researches, educational establishments, military-patriotic Education, spiritual and moral Education.

Складність та неоднозначність відображення становлення системи національно-патріотичного виховання у вітчизняному інформаційному просторі обумовлюється змінами глобального та локального характеру в соціальній, політичній, а також освітній сферах, у розробленні й прийнятті законодавчих, нормативних і концептуальних документів функціонування закладів освіти різних рівнів, розширюючи наукові засади та змістовий контур інформаційного забезпечення педагогічних досліджень 3 означеної тематики.

Останнє десятиліття характеризується стрімким розвитком веборієнтованих технологій другого покоління, впровадження яких у практику роботи книгозбірень передбачає опертя на спеціалізовані праці фахівців із формування галузевої системи бібліографічної продукції, а також розроблення архітектури проблемно-орієнтованих баз даних тематичного характеру. Такі тенденції прослідковуються і в діяльності фахівців Державної науково-педагогічної бібліотеки України імені В. О. Сухомлинського (даліДНПБ Украӥни ім. В. О. Сухомлинського), що проводяться в рамках фундаментальних та прикладних наукових досліджень, розширюючи й удосконалюючи продукування галузевої системи бібліографічних, реферативних та аналітичних документів.

Аналіз наукових досліджень i публікацій. У дослідженнях, предметом яких ставали етапи становлення класифікації бібліографічних покажчиків (далі - БП), вітчизняні дослідники загалом виокремлювали два етапи: 1) усталене визначення ознак бібліографічних покажчиків та їхнє об'єднання за визначеними ознаками; 2) уточнення Г. Швецовою-Водкою багатоаспектної класифікації, розробленої О. Коршуновим із доповненням новими класифікаційними ознаками. Спектр дискусій вирізнявся двома головними позиціями [15]. Перша - класифікація БП в епоху комп'ютеризації не актуальна, оскільки сам користувач вирішує проблему вибору документів (Е. Беспалова); друга - сформульована I. Моргенштерном, який висунув тезу про неоднозначність формування електронного інформаційного простору як однорідного масиву бібліографічних даних (далі - БД), вказавши, що він формується у вигляді сукупності різноманітних бібліографічних БД, цінність яких залежить від критеріїв виявлення, відбору та бібліографічної обробки документів [2; 6].

Позицію І. Моргенштерна підтримує Т. Опря, обгрунтовуючи його тезу про динамічність класифікації бібліографічних посібників тим, що усталена схема класифікації БП не відповідатиме появі нових видів бібліографічних посібників [9, с. 212].

Акцентуючи увагу на бібліографічних розвідках фахівців-практиків бібліографічної справи, ми спостерігаємо найбільш поширені напрями підготовки науково-допоміжних покажчиків у мережі галузевих бібліотеках: вивчення стану і перспектив системи науково-інформаційного забезпечення, огляд та аналіз підготовлених покажчиків у рамках виконання наукових проектів, упровадження інформаційно-бібліографічних систем та розроблення моделі інформаційного забезпечення, адаптованої до цільової категорії користувачів [5; 9; 10; 12-14].

На думку Л. Самчук, використання традиційних бібліографічних методів відбору, представлення та організація матеріалу гармонізується 3 електронною формою видання, що «дозволяє більш повно реалізувати потенціал цих методів і здійснити логічне наповнення структурних елементів документами, визначити форму організації і подачі матеріалу» [11, с. 180].

Підводячи підсумки діяльності ДНПБ ім. В. О. Сухомлинського впродовж 15-ти років існування книгозбірні (2014р.), Л. Пономаренко відзначає пріоритетність підготовки саме науково-допоміжних посібників, які стали «важливою складовою системи бібліографічних видань для освітянської галузі та сприяють «створенню теорії цілісного розвитку особистості, забезпеченню якісного психолого-педагогічного та науково-методичного супроводу навчально-виховного процесу на різних освітніх рівнях» [10, с. 78].

Зміна інформаційної складової, насамперед за рахунок широкого застосування автоматизованих бібліотечних інформаційних систем, зробила процес упорядкування бібліографічних видань більш динамічним та інформаційно насиченим за рахунок створення проблемно-орієнтованих баз даних.

Зазначимо, що Н. Стельмах однією із перших у ДНПБ імені В. О. Сухомлинського взяла участь у корпоративному створенні вторинної продукції в АБІС «ІРБІС», що наповнювалася бібліографічними записами, імпортованими з електронних баз даних «Книга» i «Періодика» для підготовки електронного бібліографічного покажчика «Дошкільна освіта як складова системи безперервної освіти України (1991-2006)», структура якого моделює базу даних, спроектовану «відповідно до вимог традиційного бібліографічного покажчика» [13]. 
Прослідковуючи та узагальнюючи огляд основних тенденцій розвитку науково-допоміжної бібліографії, варто відмітити цілісність сформованої галузевої бібліографічної інформації, котру представлено посібниками різних типів і видів як у традиційній, так і електронній формах, серед яких чільне місце займають науково-допоміжні бібліографічні покажчики. В той же час варто відзначити, що робота над бібліографічними покажчиками проводиться в традиційному для бібліографічної практики форматі, що впливає на результативність усього процесу. Аналітичні рефлексії та теоретичні узагальнення розширюють проблемний простір наукових розвідок з означеної проблеми, але не завжди відображаються та впливають на вдосконалення технологічних процесів підготовки бібліографічних видань.

Мета статті - проаналізувати зміст і структуру науково-допоміжного бібліографічного покажчика «Національно-патріотичне виховання в Україні»; зосередити увагу на основних складових національно-патріотичного виховання, а саме: громадсько-патріотичному, військово-патріотичному та духовно-моральному.

Виклад основного матеріалу. Серед основних форм інформаційного забезпечення галузевих бібліотек, що декларують та позиціонують особливості інформаційної підтримки реалізації документів стратегічного та концептуального характеру, слід відзначити підготовку та проведення низки заходів національно-патріотичного спрямування, в структурі яких поєднано власне бібліотечні заходи, зокрема підготовку рекомендаційних бібліографічних видань, реферативно-аналітичних оглядів, науково-методичних видань, проведення науково-практичних, науково-педагогічних, літературно-музичних виставок та форумів.

Серед значної кількості посібників різних типів і видів, підготовлених та опублікованих у рамках виконання НДР «Відображення розвитку національної освіти і педагогічної думки у друкованих та електронних виданнях» (2017-2019 рр.) (наук. керівник НДР - дійсний член НАПН України, доктор педагогічних наук, професор О. В. Сухомлинська), відзначимо науково-допоміжні покажчики із таких актуальних питань: «Реформування загальної середньої освіти в Україні у XX столітті крізь призму джерелознавства» та «Національно-патріотичне виховання в Україні» (2014-2018рр.) [1; 7].

Виняткове значення для широкого загалу має підготовка науково-допоміжного бібліографічного покажчика «Національно-патріотичне виховання» (20142018 рр.), який було опубліковано у червні 2019 року.

Актуальність теми видання обумовлена соціальними, політичними та суспільними подіями в країні, що висунули означене питання на передній план боротьби за збереження національної безпеки і зміцнення державної єдності. Патріотизм став індикатором, маркером духовної єдності народу та пробудження національної свідомості, підгрунтям морального оновлення народу. Про це свідчить і ряд законодавчо-нормативних джерел, що на найвищому рівні підтверджують увагу державних інституцій до пошуку цілісної, науково обгрунтованої моделі національно-патріотичного виховання, що охоплюватиме всі ланки системи неперервної освіти. Так, у 2015 році прийнято такі базові нормативні документи: «Стратегію національно-патріотичного виховання дітей та молоді на 2016-2020 роки», «Національну стратегію розвитку освіти в Україні на період до 2021 року», «Національну програму патріотичного виховання громадян, розвитку духовності». У Законах України «Про освіту» (2017р.), «Про правовий статус та вшанування пам'яті борців за незалежність України у ХХ ст.» (2015 р.), «Концепції національно-патріотичного виховання дітей і молоді» (2015 р.) як стратегічні, визначено завдання виховання в молоді любові до Батьківщини, усвідомлення нею свого громадянського обов'язку на основі національних і загальнолюдських духовних цінностей, утвердження якостей громадянина-патріота України.

Нові підходи до проведення систематичної роботи з питання формування всебічно розвиненої, 3 критичним мисленням особистості, патріота з активною життєвою позицією, котрий діє згідно з певними морально-етичними принципами, передбачено в освітній моделі Нової української школи (2016р.), а саме: вміння мислити, осмислювати суспільні процеси, творити себе і майбутнє своєї держави.

Значний внесок у розробку теоретичних і методологічних засад національно-патріотичного виховання здійснює Інститут проблем виховання НАПН України, зокрема I. Бех, К. Журба, співробітники лабораторії громадянського та морального виховання Інституту.

Особливої уваги заслуговують розроблені сучасні інтерактивні форми і методи удосконалення професійної компетентності фахівців із національно-патріотичного виховання. Прикладом такого навчання можуть слугувати тренінги 3 національно-патріотичного виховання для педагогічних працівників «3 Україною в серці» та тренінги для представників структурних підрозділів із питань молоді та спорту, інших фахівців соціальної сфери «Окрилені Україною». Вони проводяться в Україні з кінця 2015 року за програмами, розробленими й апробованими науковцями Інституту проблем виховання НАПН України у різних регіонах України $[4 ; 8]$.

Зрозуміло, що кожна інформаційна установа розробляє свою модель інформаційного забезпечення системи національно-патріотичного виховання, яка відповідає типу інформаційної установи, цільовій категорії читачів і користувачів. Зважаючи на те, що в мережі освітянських книгозбірень $є$ шкільні бібліотеки, бібліотеки ЗВО та інститутів післядипломної педагогічної освіти, бібліотечні установи науково-дослідних установ НАПН України, діапазон бібліографічної продукції з питань патріотичного виховання досить широкий. Це - рекомендаційні бібліографічні покажчики, рекомендаційні анотовані списки, бібліографічні огляди, огляди-дайджести та ін.

Оприлюднення результатів наукової та практичної діяльності науковців і фахівців освітянської галузі у сфері національно-патріотичного виховання, визначення перспективних напрямів наукових розвідок, упровадження їхніх результатів у діяльність закладів освіти визначено основним завданням з організації роботи авторського колективу, розробленні плану-проспекту та обгрунтуванні вибору теми науково-допоміжного бібліографічного покажчика.

Упорядники здійснили історіографічний аналіз видань $з$ означеної проблеми і виявили, що значна кількість покажчиків надає комплексний глибокий ретроспективний огляд праць із питань національно-патріотичного виховання, що, як правило, охоплює досить значний відрізок часу, нижня хронологічна межа якого співпадає 3 отриманням незалежності України (1991р.), орієнтуючись на певну цільову категорію. 
Підготовлений науковцями ДНПБ України ім. В. О. Сухомлинського науково-допоміжний бібліографічний покажчик має на меті сприяти та вдосконалювати форми і методи реалізації завдань національно-патріотичного виховання в Україні, узагальнити та впроваджувати у практику роботи закладів освіти різних рівнів творчий доробок фахівців у царині патріотичного виховання, враховуючи практичні напрацювання та прогнозуючи подальші кроки та завдання.

Досягнення високого наукового рівня підготовки бібліографічного посібника стало можливим завдяки плідній співпраці із Ж. Петрочко, науковим консультантом, доктором педагогічних наук, професором кафедри соціальної педагогіки та соціальної роботи Інституту людини Київського університету імені Б. Грінченка. Вступну статтю «Концептуальне осмислення формування у підлітків національно-культурної ідентичності в сучасних умовах» підготовлено I. Бехом, доктором психологічних наук, професором, директором Інституту проблем виховання НАПН України у співавторстві із К. Журбою, доктором педагогічних наук, старшим науковим співробітником лабораторії громадянського та морального виховання Інституту проблем виховання НАПН України. Автори акцентують увагу на національно-культурній ідентичності як складовій становлення громадянина-патріота України, що опирається на моральні цінності, сприятиме формуванню в молоді національного духу, національної свідомості та самосвідомості.

Основним принципом упорядкування та групування бібліографічних записів було обрано структуру системи неперервної освіти, що відобразилося у назвах розділів, а також у виокремленні військово-патріотичного виховання та волонтерської діяльності як окремих структурних компонентів групування документів. Покажчик містить 2722 бібліографічних записи, опублікованих/оприлюднених упродовж 2014-2018 років та вміщених у восьми розділах.

Розділ I. "Національно-патріотичне виховання в новому історичному осмисленні» складається із двох підрозділів: 1.1. «Нормативно-правове забезпечення начіонально-патріотичного виховання» та 1.2. "Начіонально-патріотичне виховання як наукова проблема». У першому підрозділі згруповано бібліографічні описи нормативно-правових актів України, що законодавчо закріплюють пріоритети та напрями національно-патріотичного виховання дітей і молоді у діяльності відповідних інститутів держави та суспільства; у другому - сфокусовано увагу на документах, у змісті яких відображено напрями, тенденції, викладено результати наукових розвідок, узагальнень, рефлексій, стрижневою ідеєю яких стає виховання громадянина-патріота.

У розділі II «Виховання громадянина-патріота у творчій спадщині видатних педагогів України» відображено погляди видатних українських педагогів, філософів, психологів, громадсько-політичних діячів на роль і значення національно-патріотичного виховання дітей та молоді. Безумовно, що він має яскраво виражений персоналістичний характер. Узагальнюючи зміст цього розділу, варто виділити такі основні напрями досліджень: теоретичні та практичні аспекти національно-патріотичного виховання в історичній і регіональній ретроспективі; історіографічний аналіз ідей національно-патріотичного характеру відомих особистостей в публікаціях сучасних науковців; вивчення та застосування ідей відомих педагогів, філософів у навчальному процесі закладів освіти.
Зміст розділу ІІІ «Національно-патріотичне виховання в системі дошкільної освіти» складають документи, де вміщено інформацію про практичний досвід проведення виховних заходів, проектів національно-патріотичного спрямування в закладах дошкільної освіти різних типів і видів.

Проблематика розділу IV «Національно-патріотичне виховання у закладах загальної середньої та професійної (професійно-технічної) освіти» досить різноаспектна і відображає специфіку проведення роботи 3 національно-патріотичного виховання відповідно до завдань та форм його проведення у навчальних закладах, що згруповані в окремі структурні сегменти. Так, до підрозділу 4.1. «Загальна середня освіта» включено матеріали, в яких висвітлено національно-патріотичну складову в процесі викладання різних предметів; представлено інформацію про тематику виховних заходів у системі позакласної роботи; описано досвід організації та проведення спільних заходів патріотичного характеру з батьками та громадськістю. У підрозділі 4.2. «Професійна (професійно-технічна) освіта» вміщено бібліографічні описи документів, що відображають реалізацію завдань національно-патріотичного змісту через низку заходів, спрямованих на виховання в учнів почуття національної гідності та національно-культурної ідентичності шляхом пошуку нових ефективних форм і методів впливу на становлення патріотично свідомого майбутнього фахівця, здатного до вироблення власної патріотичної позиції.

У розділі $\boldsymbol{V}$ «Національно-патріотичне виховання в закладах вищої та післядипломної педагогічної освіти» представлено матеріали, що свідчать про стан та орієнтири вдосконалення системи національно-патріотичного виховання в означених вище ланках освіти; розглянуто напрями патріотичного виховання в закладах гуманітарного, правничого, технічного профілю у процесі викладання навчальних дисциплін природничого, математичного, економічного циклу; висвітлено етнонаціональні та народознавчі складові здійснення національно-патріотичного виховання в навчальному процесі та в позааудиторній діяльності; проаналізовано участь студентської молоді та науково-педагогічних працівників у волонтерській діяльності, роботі громадських організацій, утіленні молодіжних соціальних ініціатив.

У розділі VI «Реалізація національно-патріотичного виховання в закладах позашкільної освіти та громадських об'єднаннях» представлено публікації, що висвітлюють роботу культурно-освітніх, спортивно-оздоровчих, науково-пошукових об'єднань, предметних гуртків, секцій національно-патріотичного звучання. Зокрема, розглянуто хортинг як різновидність національного спорту та важливий елемент національно-патріотичного виховання; висвітлено роботу спортивно-просвітницьких організацій, туристичних, скаутських організацій, віртуальних спільнот. Виокремлено роботу шкільних історико-краєзнавчих музеїв як важливу складову патріотичного виховання.

У розділі VII «Доброчинна та волонтерська діяльність в системі національно-патріотичного виховання» вміщено бібліографічні описи публікацій про внесок волонтерів, активістів у зміцнення обороноздатності України, підтримання морально-психологічного забезпечення сучасного українського війська школярів та студентів у волонтерських організаціях, зокрема у справі опікування над родинами учасників АТО, інформування про учасників бойових дій. 
Значна кількість публікацій, котрі вміщено у розділі VIII «Військово-патріотичне виховання молоді як відповідь на виклики часу» присвячена проблемам військово-патріотичного виховання. Доведено, що ефективність реалізації поставлених завдань значною мірою залежить від форм і методів підготовки старшокласників до захисту Вітчизни в умовах закладів середньої та вищої освіти, а також у закладах військової освіти, у процесі фахового вишколу особового складу Збройних Сил України. Тут також містяться відомості різноманітні аспекти проблеми залучення молодого покоління до участі в загальнодержавних військово-патріотичних заходах. Суттєве значення в структурі восьмого розділу займає низка публікацій щодо духовно-морального виховання майбутніх військовослужбовців, військової еліти, зокрема детально описано результати педагогічних досліджень щодо вивчення стану сформованості у військових готовності захищати батьківщину; викладено результати експериментальних робіт, проведених викладачами військових закладів вищої освіти i науковців Інституту проблем виховання НАПН України. Серед публікацій, які увійшли до цього розділу, наявний досить потужний інформаційний пласт досліджень, які стосуються застосування прикладного хортингу під час викладання дисциплін «Захист Вітчизни», «Допризовна підготовка».

До покажчика також увійшли друковані матеріали: статті з періодичних видань, доповіді та повідомлення, підготовлені в рамках науково-теоретичних і науково-практичних конференцій, семінарів, «круглих столів», автореферати дисертацій. Чималий за обсягом пласт документів представлено в електронному вигляді. За типовидовим складом - це статті зі збірників наукових праць, матеріали інтернет-конференцій, тематичні рубрики і збірки із мережевих ресурсів, сайтів бібліотек, інформаційних, наукових установ. Хронологічні рамки науково-допоміжного бібліографічного видання - 2014-2018 роки.

Унікальним і в певному сенсі експериментальним елементом видання стали матеріали інформаційних ресурсів, розміщені на глобальній платформі EBSCO Publishing. Це невеликий за обсягом, але, на нашу думку, перспективний інноваційний тренд, що в подальшому може стати затребуваним при формуванні бібліографічних видань галузевими книгозбірнями.

Видання розраховане на викладачів, науковців, студентів, учителів, бібліотечних працівників, тобто тих, хто виявляє інтерес до питань національно-патріотичного виховання. Рецензоване бібліографічне видання поповнить джерельну базу з актуальних питань національно-патріотичного виховання, сприятиме подальшому впровадженню наукових досягнень у роботу закладів освіти, орієнтуватиме фахівців на визначення та прогнозування методів вирішення необхідних для суспільства проблем в означеній науковій сфері.

Висновки. Узагальнюючи результати бібліографічного дослідження 3 питань національно-патріотичного виховання, виокремимо основні міркування щодо бібліографічних досліджень означеної тематичної спрямованості.

По-перше, в теоретичному вимірі класифікація тематичних науково-допоміжних бібліографічних видань має дискусійний, постійно доповнюваний новими акцентами змістовий контур і контекст.

По-друге, результати бібліографічних розвідок із «вузьким» хронологічним діапазоном, що акцентують увагу на суспільно значущій тематиці, відображаються насамперед у публікаціях в електронному форматі, що відповідає імперативам розвитку інформаційно-комунікаційних технологій.

По-третє, ущільнення хронологічних рамок дослідження орієнтує автора до багаторівневого «занурення» в інформаційний простір досліджуваної проблеми: від сторінки в мережі Інтернет закладу дошкільної освіти відповідного тематичного спрямування до фундаментального наукового доробку фахівців в означеній науковій ділянці.

\section{СПИСОК ВИКОРИСТАНОЇ ЛІТЕРАТУРИ}

1. Березівська Л. Д. Реформування загальної середньої освіти в Україні у ХX столітті крізь призму джерелознавства : наук.-допом. бібліогр. покажч. / Л. Д. Березівська. - Вінниця : ТОВ «ТВОРИ», 2019. $251 \mathrm{c}$.

2. Беспалова Э. К. Тема, принадлежащая истории: классификация библиогр. Пособий / Э. К. Беспалова. 1999. - № 4. - С. 151-152.

3. Бех І. Д. Програма українського патріотичного виховання дітей та учнівської молоді / І. Д. Бех, К. І. Чорна. - Київ, 2014. - 29 с.

4. Бех І. Д. 3 Україною в серці (тренінг із патріотичного виховання дітей та молоді) : посібник / І. Д. Бех, Ж. В. Петрочко, В. І. Кириченко. Київ : Ін-т обдар. дитини НАПН України, 2015. $182 \mathrm{c}$.

5. Лисиця Н. В. Бібліографічна продукція ДНПБ України ім. В. О. Сухомлинського як складова інтегрованого галузевого інформаційного ресурсу / Н. В. Лисиця, Н. А. Стельмах // Наукові праці Державної науково-педагогічної бібліотеки України імені В. О. Сухомлинського. - 2014. - Вип. 4. C. $120-128$.

6. Моргенштерн И. Г. Понятийный аппарат библиографической деятельности в электронной среде / И. Г. Моргенштерн // Мир библиографии. - 2004. № 6. - C. $8-12$.

7. Національно-патріотичне виховання в Україні : наук.-допом. бібліогр. покажч. / упоряд. : Л. І. Страйгородська, Л. О. Пономаренко, С. В. Тарнавська та ін. ; наук. ред. Л. Д. Березівська. - Київ, 2019. - 368 с.

8. Опря Т. М. Покажчики як форма розповсюдження бібліографічної інформації / Т. М. Опря // Наукові праці Кам'янець-Подільського національного університету ім. І. Огієнка. Кам'янець-Подільський : Аксіома, 2013. - Вип. 3. - С. 211-215. - (Серія : Бібліотекознавство. Книгознавство). URL: http://nbuv. gov.ua/UJRN/npkpnuiobk_2013_3_36 (дата звернення: 21.08. 2019).

9. Петрочко Ж. В. Окрилені Україною (тренінг із національно-патріотичного виховання молоді) : посібник / Ж. В. Петрочко, В. І. Кириченко. - Харків : Панов А. М., 2016. - 134 c.

10. Пономаренко Л. О. Електронні бібліографічні ресурси Державної науково-педагогічної бібліотеки України імені В. О. Сухомлинського в інформаційному просторі: стан та проблеми розвитку // Наукові праці Державної науково-педагогічної бібліотеки України імені В. О. Сухомлинського. - К. : Педагогічна думка, 2014. - № 4. - C. 76-84. URL: http://nbuv. gov.ua/UJRN/npdnpbc_2014_4_9 (дата звернення: 20.08.2019). 
11. Самчук Л. І. Створення електронних бібліографічних посібників в дерсжавній науково-педагогічній бібліотеці України імені В. О. Сухомлинського / Л. І. Самчук // Вісник ОНУ. - Одеса : ОНУ, 2018. - Т. 23. - № 1. - С. 179-186. - (Серія: Бібліотекознавство, бібліографознавство, книгознавство). URL: http://vislib.onu.edu.ua/article/view/122671/131849 (дата звернення: 20.08.2019).

12. Складання бібліографічних посібників : інформ.-метод. матеріали / уклад. О. Галганова ; наук. ред. В. Кононенко. - Київ, 2015. - 80 с.

13. Стельмах Н. Інформаційно-бібліографічне забезпечення наукових досліджень із питань дошкільної освіти / Н. Стельмах // Вісник Книжкової палати. 2009. - № 7. - С. 18-21.

14. Трачук Л. Ф. Вебліографічні посібники бібліотек як джерела електронного довідково-бібліографічного обслуговування / Л. Ф. Трачук // Бібліотечний вісник. - 2011. - № 5. - С. 29-35.

15. Швецова-Водка Г. М. Вступ до бібліографознавства : навч. посіб. для студ. вищ. навч. закл. / Г. М. Швецова-Водка. - Київ : Кондор, 2004. $217 \mathrm{c}$.

Дата надходження до редакиї: 05.09.2019 р.

Володимир ЛАВРЕНЧУК, кандидат філологічних наук, дочент, завідувач кафедри суспільно-гуманітарної освіти Рівненського ОІППО

Марія ЛАВРЕНЧУК,

методист кабінету суспільно-гуманітарних предметів Рівненського ОІППО

\section{ЦІННІСНІ КОНЦЕПТИ ВАСИЛЯ СУХОМЛИНСЬКОГО В КОНТЕКСТІ НОВОЇ УКРАЇНСЬКОЇ ШКОЛИ}

\begin{abstract}
У статті проаналізовано концептуальні засади Нової украӥнської школи у суголоссі із філософськометодологічними концептами педагогічної спадщини В. Сухомлинського. Звернено увагу на такі иіннісні кониепти видатного педагога, як людиночентризм; дитиноцентризм; сповідування сімейних иінностей; иіннісний концепт слова, мови, літератури, мовної картини світу; кордоцентризм.
\end{abstract}

Ключові слова: концепт, иінності, Нова украӥнська школа, емпатія, кордоцентризм.

В статье проанализированы кониептуальные основы Новой украинской школь в сравнении с философско-методологическими кониептами педагогического наследия В. Сухомлинского. Выделены такие иенностные концепты выдающегося педагога, как человекоиентризм; ребенкочентризм; исповедание семейных иенностей; иенностный кониепт слова, языка, литературы, языковой картины мира; кордоиенттизм.

Ключевые слова: концепт, ценности, Новая украинская школа, эмпатия, кордочентризм.

The article is concerned with the concept of values of Vasyl Sukhomlynsky's inheritance. The authors analyze this issue in the context of the conceptual approaches of the New Ukrainian School. The concept is considered as an innovative idea that includes the content and the gist of the modern education. Referring to the new Education Regulations, namely the concept of the New Ukrainian School, the Law of Ukraine on Education, the authors come to the conclusion that the concept of values in the Vasyl Sukhomlynsky's teaching principles formed the basis for the concept of the New Ukrainian School and other Education Regulations. The given examples illustrate the maintaining of the continuity of the attitude to the concept of values of the famous pedagogue with the concept of values of the modern education in Ukraine and all around the world. The article deals with such concepts of values as happiness, empathy, childcentrism, Philosophy for children, I-Concept, and holistic perception of the language picture of the world.

According to Vasyl Sukhomlynsky, formation of emotional intelligence is a holistic system of development, upbringing and education that is based on the humanistic ideas of goodness and beauty.

Language and literature, as school subjects, are the source of morality and spirituality that cherishes the human virtues and eternal values. They develop the key competencies and the holistic perception of the world.

The language code identifies the national authenticity, uniqueness and consolidates the speakers for the evolution and sustainability.

Key words: concept, values, New Ukrainian School, empathy, philosophy for children, language picture of the world, eternal values, heart-centered philosophy. 